\section{Hidden depth: tracing corporate ownership and its implications in the U.K. defense industry}

\section{Derek Braddon}

$\mathrm{T}$

he ownership of both U.K. and global defense industries is being dramatically transformed. In part, this ownership revolution represents a natural adjustment to the post-Cold War world with its new and challenging geopolitical requirements, evolving military strategies, new technologies, and the emergence of competitive new suppliers. The symbiotic government-defense company relationships (which in earlier decades created the so-called military-industrial complex) have largely been replaced by a more competitive, increasingly global market for defense procurement in which corporate efficiency and product cost-effectiveness are paramount. Governments still have considerable influence in defense procurement, and many still seek to protect and promote their respective national champions. But the game has changed, fundamentally and irrevocably, and market forces now play an ever more important role in the defense procurement process.

In such a situation, the dynamics of defense company ownership takes on new significance. To what extent, for example, does the ownership revolution in defense create or secure market power? Could the ownership of defense companies by particular kinds of investors (and their country of origin) positively or adversely affect their, or a government's, military strategies and outcomes? Are there important corporate governance issues involved in the transfer of ownership that might influence or constrain corporate behavior? At a time when alleged corporate scandals in the defense industry have become prominent in the media, these issues take on even greater importance.

This article seeks to address questions such as these in an area of defense economics that has been little explored. ${ }^{1}$ It does so at two levels: first, at the level of the company, where takeovers, mergers, and strategic alliances across the industry are changing fundamentally the commercial landscape; and second, at the level of the shareholder where ownership takes on a new meaning and where best-practice corporate governance is expected and indeed has become a barometer by which corporate behavior is being increasingly judged. The article offers some reflections on the complex and somewhat obscure territory of defense company ownership and related behavior and on this central question: does defense company ownership actually matter?

The ownership issue

Thirty years ago, discussion about corporate ownership and its implications in the
U.K. defense sector would have been largely irrelevant. Almost all major defense supply companies were government controlled and with very limited private sector influence. It was only after the advent of privatization in the United Kingdom in 1980 that the country's major defense prime contractors moved back into the private sector

For example, in 1981, British Aerospace were part-privatized with 50 percent of the shares being sold to the public. The remainder were sold in 1985 with the British government retaining a "golden share" in the company. Rolls-Royce became a public limited company in 1985 with a stock market float in 1987, the government again retaining a golden share. In 1986, Royal Ordnance was placed on the market with its tank division sold to the Vickers company and the remainder offered as package to the highest bidder, and eventually becoming part of British Aerospace. Shorts of Belfast, the shipbuilders, was sold in 1989 to the highest bidder (Bombardier of Canada). Other state-owned, defense-related shipyards in the U.K. were sold separately, some as management buyouts, in the mid-1980s.

More recently, the government-run Defence Evaluation and Research Agency, formed in 1995, was effectively divided into two sections, one retained under government control (DSTL) and the other transformed into QinetiQ, a private-public partnership with the U.S.-owned Carlyle Group. QinetiQ was floated on the stock market in 2006 and has become a FTSE-250 company. The U.K. government again retain a golden share in this company.

The privatization of the U.K.'s major defense companies since 1980 has been part of a continuing drive for enhanced value for money in defense procurement. From the Levene reforms of the mid-1980s, through the 1992 Competing For Quality initiative, to the Smart Procurement and Smart Acquisition strategies that have dominated procurement reform in the last decade, to the Defence Industrial Strategy of 2005, the U.K. Ministry of Defence has focused with increasing intensity and varying degrees of success on trying to ensure maximum cost-effectiveness in the deployment of the defense equipment budget. ${ }^{2}$

Globally, too, the defense industry is currently experiencing a degree of corporate metamorphosis which is unprecedented. Three important developments explain the revolution in defense company ownership. First, following the end of the Cold War in 1989-1990 and the dramatic reduction in defense procurement budgets, the industry and the defense sector more generally underwent considerable corporate restructuring and more recent developments have led to it undergoing further rapid transformation. ${ }^{3}$ Second, following the terrorist attacks of 11 September 2001 and the more recent Madrid and London bombings, the whole concept of what defense and security actually mean in practice changed fundamentally. Coincident with military operations in Afghanistan and Iraq this engendered a new increase in some defense budgets, principally in the United States, where considerations of homeland security and dealing with the "axis of evil," as it was perceived, pushed defense budgets upward again. Critically, in this new resurgence of defense spending, the kind of military procurement required has changed and, as a result, new kinds of defense companies 
have been drawn into supplying the defense sector.

The third important development concerns the changing technical nature of defense provision and strategy. Major advances in a range of technologies have enabled the military in countries like the U.S. and U.K. to pursue a completely new kind of warfare strategy. The advent of network-enabled capabilities and networkcentric warfare has changed fundamentally the kinds of goods and services required by the military and also the strategic response, processes, and procedures to be used in future conflict resolution. The so-called Revolution in Military Affairs (RMA) and the evolving "rapid reaction" approach to military doctrine, with its associated humanitarian requirements, network-centric warfare developments, and homeland security issues linked to the terrorist threat, have brought - and will continue to bring - new players and new owners into the defense supply business of the future.

The issue of defense company ownership in the U.K., therefore, takes on a greater urgency with the recognition of the revolution currently sweeping through the global defense industry, changing fundamentally its character, location, focus, and modus operandi. ${ }^{4}$ Every aspect of the defense sector is being reconfigured from defense budgets, through procurement policies and military objectives and strategy to leadingedge technological developments designed to meet the requirements of the move toward network-centric warfare..$^{5}$ These changes are certain to result in a further fundamental restructuring of the U.K. defense industrial base. ${ }^{6}$ Major ownership changes have already occurred, ${ }^{7}$ and, as the revolution spreads further through the supply base of the industry, ${ }^{8}$ further ownership adjustments seem inevitable.

\section{Visible ownership}

Driven by the important developments in the defense sector outlined above, the recent consolidation of the defense industry has created a complex, inter-dependent cobweb of transnational corporate ownership - a "spaghetti bowl" maze that, while occasionally hard to trace and disentangle, is at least visible to the researcher. In 2006, 31 organizations received more than $£ 100 \mathrm{~m}$ from the U.K. Ministry of Defence. ${ }^{10}$ Five of these organizations were government agencies (e.g., DSTL, NETMA) and a further eight were essentially service providers (e.g., BT, BP, the Met Office). Twelve U.K. companies and six multinational or non-U.K.-owned organizations were in this category, and it is within this highly defense-dependent subgroup and their principal suppliers that the visible ownership picture has been transformed.

Take, for example, the case of BAE Systems. The visible ownership dimension of BAE Systems in May 2005 is depicted in Figure $1 .{ }^{11}$ The linkages of the company at that time were wide-ranging and extended globally across the industry. Within its ownership domain were: Royal Ordnance Defence, Alvis, and 50 percent of Fleet Support Ltd in the UK; 37.5 percent of MBDA, the transnational European guided weapons supplier; 100 percent of the Swedish defense contractors Haaglunds and Bofors, through the U.S. arm of BAE and 35 percent of Saab AB, among others. The

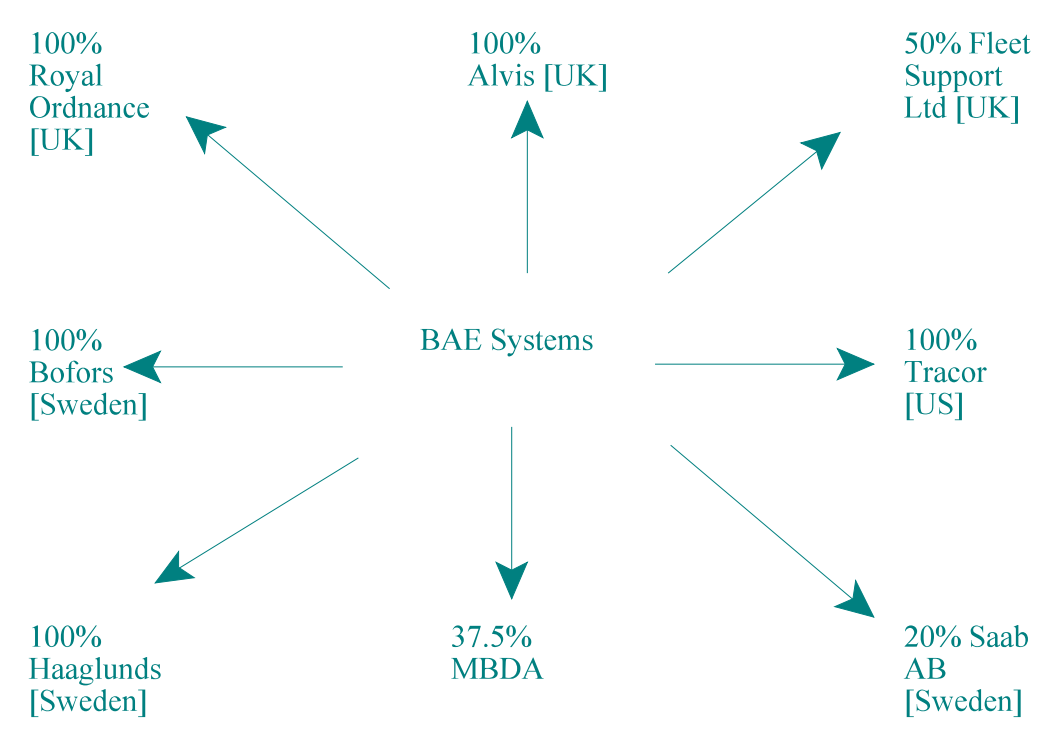

Figure 1.

ongoing ownership revolution in the defense industry is frequently more extensive than it seems on the surface and can exert a significant influence on procurement success in different markets. For example, the takeover of Marconi Electronic Systems by BAE in January 1999 gave BAE control of Tracor, an American electronics company, acquired by GEC Marconi in 1997. With 10,000 U.S. employees, Tracor became at the time the largest U.S. defense enterprise owned by a European-based company. Critically for BAE Systems, this ownership move allowed the company enhanced opportunities in the lucrative and expanding U.S. market.

Additional ownership changes helped to further strengthen the position of BAE Systems in the U.S. market. In April 2000, BAE gained ownership of Lockheed Martin Control Systems (a flight controls designer and manufacturer) and in July 2000 became owner of Lockheed Martin's Aerospace Electronics business division as well. Such acquisitions have given BAE Systems an employment footprint in the U.S. of over 25,000 and have assisted the company to obtain important contracts with U.S. prime contractors and led to the official recognition in 2003 of BAE Systems as an "American" company by the Pentagon in the context of its defense procurement strategy.

In Figure 2, a similar visible ownership picture is displayed for Rolls-Royce Plc, 


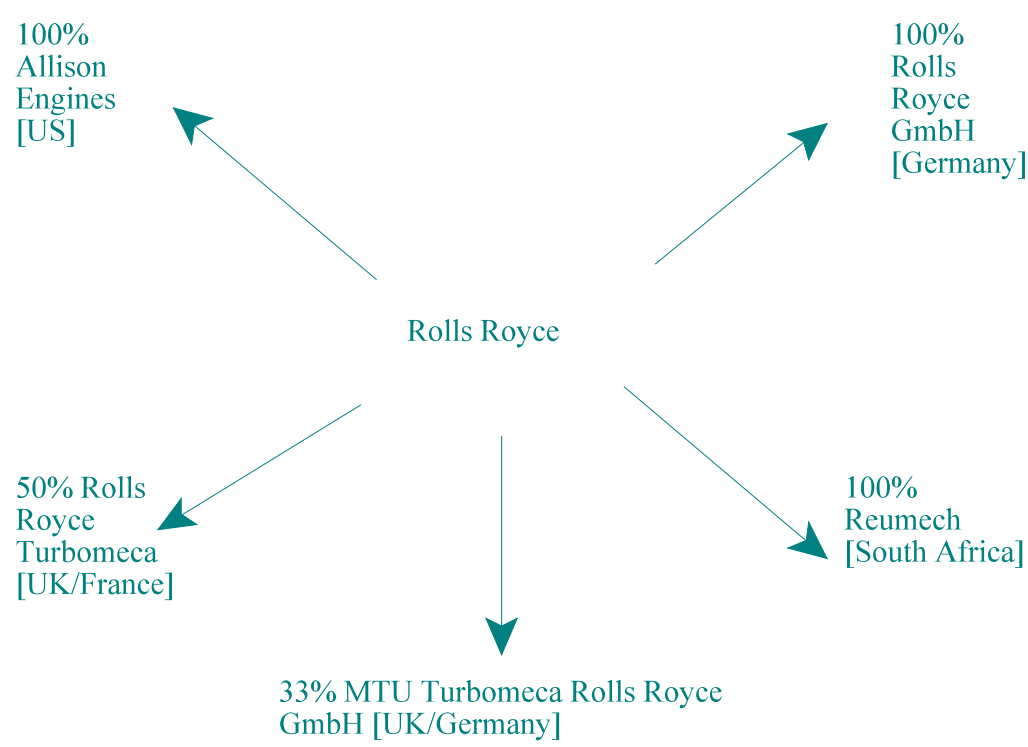

Figure 2.

again for May 2005. In 2005, Rolls-Royce owned both the U.S. aero-engine company, Allison, and the German aero-engine organization, Rolls-Royce GmbH. It also owned half of the Anglo-French aero-engine company Rolls-Royce Turbomeca and one third of the Anglo-German aero-engine company MTU Turbomeca Rolls-Royce (MTR) $\mathrm{GmbH}$. The South African light-armored vehicle manufacturer Reumech was also owned by Rolls-Royce, and the company is a partner in other global co-ownership arrangements with a 50 percent stake in Rolls-Royce Services Limitada, Inc. (the Philippines), an aero-engine maintenance company. It also controls 46.8 percent of IPT SA (Spain), among others. Such cross-shareholdings, partnerships, joint ventures, strategic alliances, and industrial teamings are now commonplace within global high technology industries and are likely to become even more prominent in the defense industrial sector as the technology-shift implicit in the current RMA brings an even wider range of nontraditional players in to the military supply market.

An example of developing global visible ownership links on the high technology side of the defense industry is provided by the case of QinetiQ, depicted in Figure 3. QinetiQ was established as a corporate organization in July 2001, the world's first leading-edge national defense laboratory to move into private sector ownership. The company now owns three U.K. concerns: HVR Consulting, Broadreach Networks, and Graphics Research and also owns Verhaert Designs in Belgium. In the U.S.,

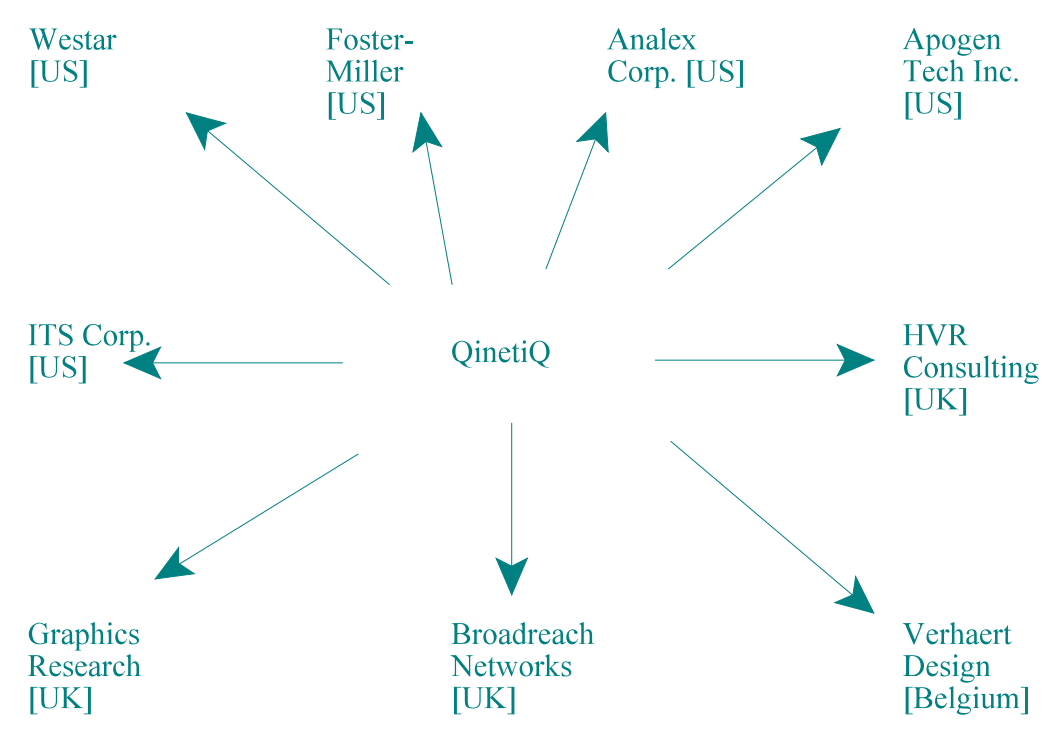

Figure 3.

QinetiQ owns the computer software and support company Westar Aerospace and Defense Group as well as the engineering and technology development company Foster-Miller, Inc. Following full privatization in 2006, ownership of additional foreign-based companies was pursued and the company now has ownership of U.S. companies Analex Corporation, ITS Corporation, and Apogen Technology, Inc.

Within the U.K. defense industry supply chain, too, similar visible ownership changes have been prominent. Smiths Aerospace, a major first-tier supplier to the U.K. aerospace and defense market (and part of the Smiths Group) owns U.S.-based ETI Technology, Inc., SensIR Technologies, LLC, and TRAK Communications, Inc. Smiths also own the Chinese-based Tianjin Timing Seals Co., Ltd and its associated technology. They further acquired the U.S. company Integrated Aerospace, Inc., a privately owned, California-based supplier of specialist landing gear systems and also Dynamic Gunver Technologies, a specialist aero-engine component manufacturer. However, in 2006, a major ownership development occurred when the major U.S. conglomerate General Electric itself captured ownership of Smiths' Aerospace Division for some $£ 2.45 \mathrm{bn}$, placing another newly American-owned supplier right at the heart of U.K. defense procurement.

Cobham Plc is another U.K.-based first-tier defense supply company that has now been transformed into a globally-focused aerospace and military goods supplier which 
offers a world-class range of niche products and systems for aerospace, marine, homeland security, and other customers. Cobham now owns around 70 companies across the world, including ACR Electronics, Inc. in the U.S., Air Precision SA in France, Chelton Applied Composites in Sweden, Drager Aerospace in Germany, Falcon Special Air Services in Malaysia, Mastsystem International Oy in Finland, National Jet Systems Pty Ltd in Australia, Orion in Canada, and also Spectronic Denmark A/S in Denmark.

Similar acquisition strategies by the key players in defense markets outside the U.K. also impact on the ownership issue. For example, the acquisition of the U.K company Racal by Thomson-CSF in 2000 made the French company the second largest defense company operating in the U.K. and enabled it to use its British operations to access the U.S. market more easily.

\section{Invisible ownership: who really owns the U.K.'s defense companies?}

At the visible ownership level, then, the U.K.'s defense-related corporate infrastructure has changed dramatically in recent years. However, hidden beneath the "spaghetti bowl" of evolving U.K. and European defense industry restructuring lies an equally important level of ownership, one which is much less visible, namely that of the capital providers to the industry.

The categories of capital required by a defense company should, in principle, be identical to those in any other commercial enterprise. Such capital requirements would include equity share capital, bonds and convertible stocks (securitized borrowings, some of which may have the status of quasi-equity) and borrowings from banks and other financial institutions. Effectively, these become the liabilities on the company's balance sheet and the providers of these forms of capital become the beneficiaries of capital returns generated by the defense industry. In the main, though, it is primarily share capital which will generate ownership rights over the company, giving the potential for some degree of influence or control over corporate decisionmaking.

Financial investors will be attracted to invest in defense supply companies for several reasons. First, the ultimate consumers for the output of the defense industrial sector will primarily be governments and, as such, they represent a more favorable credit risk than customers from the private market. Except in extreme circumstances, governments are unlikely to renege on their defense procurement commitments, implying lower risk for the investor and, consequently, a higher, more attractive risk-adjusted return. Second, once governments have committed to a military purchase, investors will recognize that the defense contractors concerned (in whom they might invest) are now likely to have enhanced negotiating power which can be deployed to their commercial advantage, given the vulnerability of government to interruptions in supply. With the exception of periods when defense budgets are contracting sharply, prime defense contractors are considered by investors to be in a relatively privileged position as commercial enterprises and therefore remain extremely popular with capital providers

The data required to identify the invisible ownership dimension of the defense industry in the U.K. is much less easily accessed than the visible ownership aspect which receives widespread media coverage on an almost daily basis. However, shareholding information is available to researchers as most major defense companies have a formal listing on one or more stock exchanges and either they, or some other public authority, often require the disclosure of major equity holdings. This may be accessed through the annual report and accounts of the companies concerned or, in some parts of the world, it is possible for members of the public to access a copy of the shareholders' register on payment of a fee. Again, researchers can access shareholder information on specialist databases (as in the case of the FAME database employed in this study). ${ }^{12}$ Securitized debt may be held in registered form but this may not be available for public access and owners here are less easy to identify than shareholders. Bearer bonds are not registered and it is therefore essentially impossible to determine ownership. As with personal bank accounts, bank lending to companies is usually confidential, although large syndicated loans may well be in the public record but are notoriously difficult to research.

Most shareholders will have the same legal status but in some ways relevant to this study they will differ significantly from each other. The differences are likely to be in terms of size of shareholding (measured as a proportion of total share capital, or of total "free" share capital), the time period over which the shares are held, and the degree of activity or passivity of the shareholders in relation to corporate votes and actions. For the purpose of this particular piece of research, the most interesting shareholdings in U.K. defense companies would be those significant strategic stakes held by commercial or industrial groups with multinational or other defense interests and by foreign shareholders and/or foreign governments and their agencies. In addition, the researcher would be seeking to identify potential covert or overt connections, networks, cartels, or other kinds of industrial agreements that may exist among the capital providers.

The evidence and does it matter?

This section of the article reports the key findings of a recent pilot study conducted into this rather opaque area of defense company ownership. It must be recognized from the outset that the very nature of global stock market behavior highlights the process of continual share acquisition or disposal - hence, the shareholder register of a public listed company will inevitably be changing most of the time. Significant shifts in the overall profile of corporate ownership can occur quite quickly. Data were derived from the FAME database in mid-2006 and the picture painted by the data of ownership profiles is, in effect, simply a snapshot in time. The figures discussed should therefore be seen as generating an ownership snapshot at one particular moment in time and nothing more. Data for a period before or after that moment 
61 shareholders $>0.1 \%$ shareholdings; U.S. ownership $26 \%$

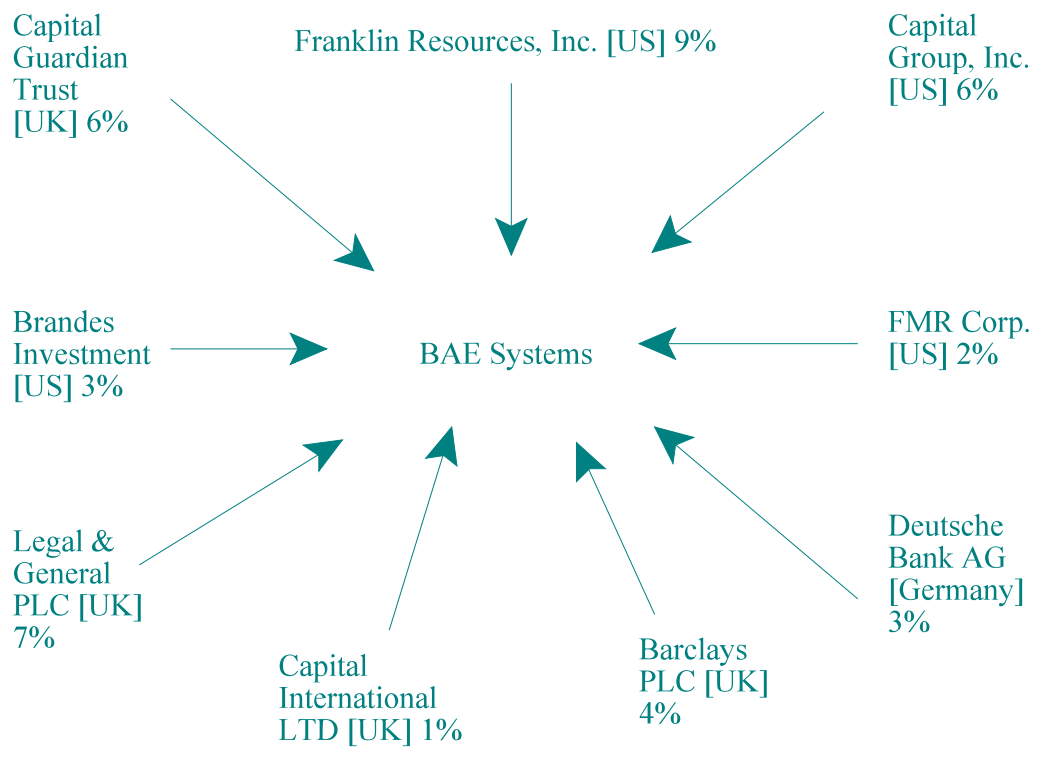

Figure 4.

would have been slightly different, although major shareholders in practice tend to change much more slowly, making it possible to derive both important trends over time and comparisons between ownership profiles of different companies.

In the pilot study, shareholding data was examined for two major U.K. defense companies, BAE Systems and Rolls-Royce Plc, and also for a third company at a lower tier of the defense industry supply chain, namely Cobham Plc. Despite the data limitations, the ownership picture that emerges is interesting and will inform the next phase of research where the process will be repeated for a greater number of companies and examined over a longer period of time.

What, then, does the invisible ownership picture reveal for the mentioned cases? Figure 4 shows the picture in mid-2006 for BAE Systems. ${ }^{13}$ A total of 61 shareholders in BAE Systems in mid-2006 had shareholdings exceeding 0.1 percent of total company shares, meaning that the ownership spread is extensive with many small shareholdings. The top-5 investors by percentage shareholding at the time controlled some 32 percent of the company. This figure has increased significantly from just 19.9 percent two years earlier. ${ }^{14}$ Ownership concentration appears therefore to be tightening although the investors involved appear genuinely unconnected. Three of them were American and all of them appeared to be passive investment managers rather than industrial groups investing for reasons of corporate strategy.
53 shareholders $>0.1 \%$ shareholdings; U.S. ownership $45 \%$

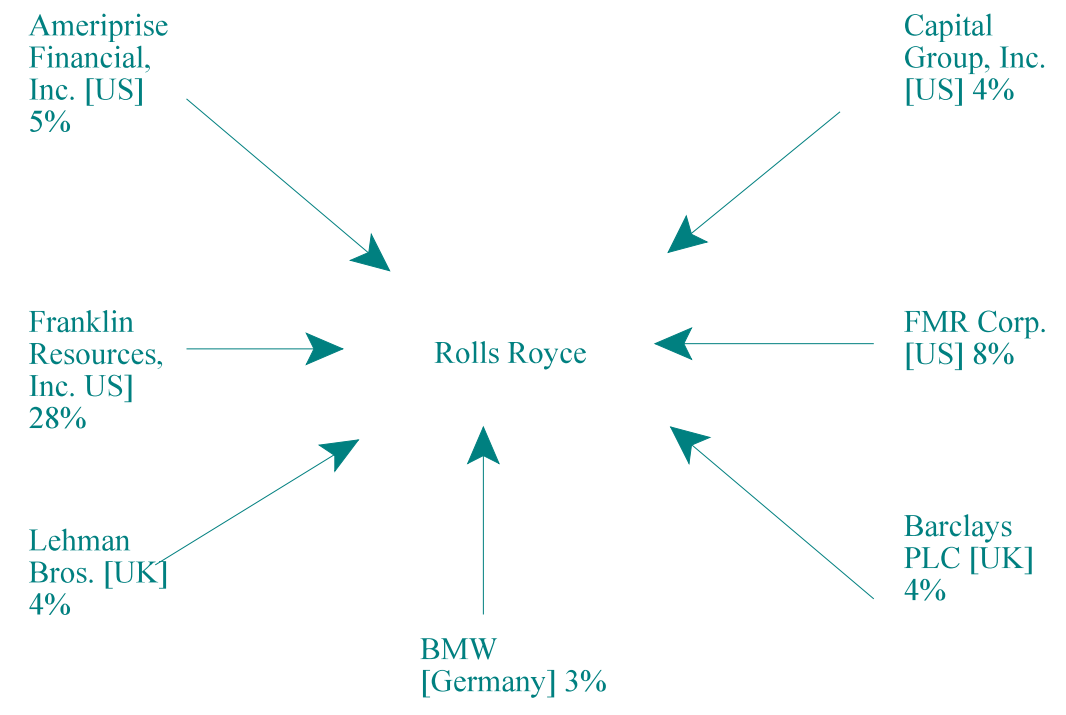

Figure 5.

It appears from this snapshot that BAE Systems has an international and widespread share register in which no single investor, or connected group of investors, has a significant strategic stake. This profile is consistent with the BAE System's commercial position as a major competitor in global defense markets. Both in 2004, and as shown here for 2006, the principal owners of the company were American and British portfolio investors. This is not to say that these owners have no influence at all over company attitudes and behavior; it is simply that their investments would take on much greater strategic significance if these capital providers became less passive and more active investors with shared objectives in terms of corporate policy influence. It is also worthy of note that, as BAE Systems have moved increasingly closer to the U.S. defense market (earning, as noted earlier, formal Pentagon recognition), major U.S. shareholdings in the company have increased from around 12.6 percent of total shares in 2004 to about 26 percent in 2006 . This is an important trend and one which will be discussed further in the next section of the article.

Figure 5 presents a similar principal shareholding profile for Rolls-Royce Plc as of mid-2006. Rolls-Royce, like BAE Systems, is a publicly listed company but, unlike that major prime contractor, the company has a much more concentrated share register where American interests are even more in evidence. Some 53 key shareholders each own more than 0.1 percent of total shares, although many of these individual 


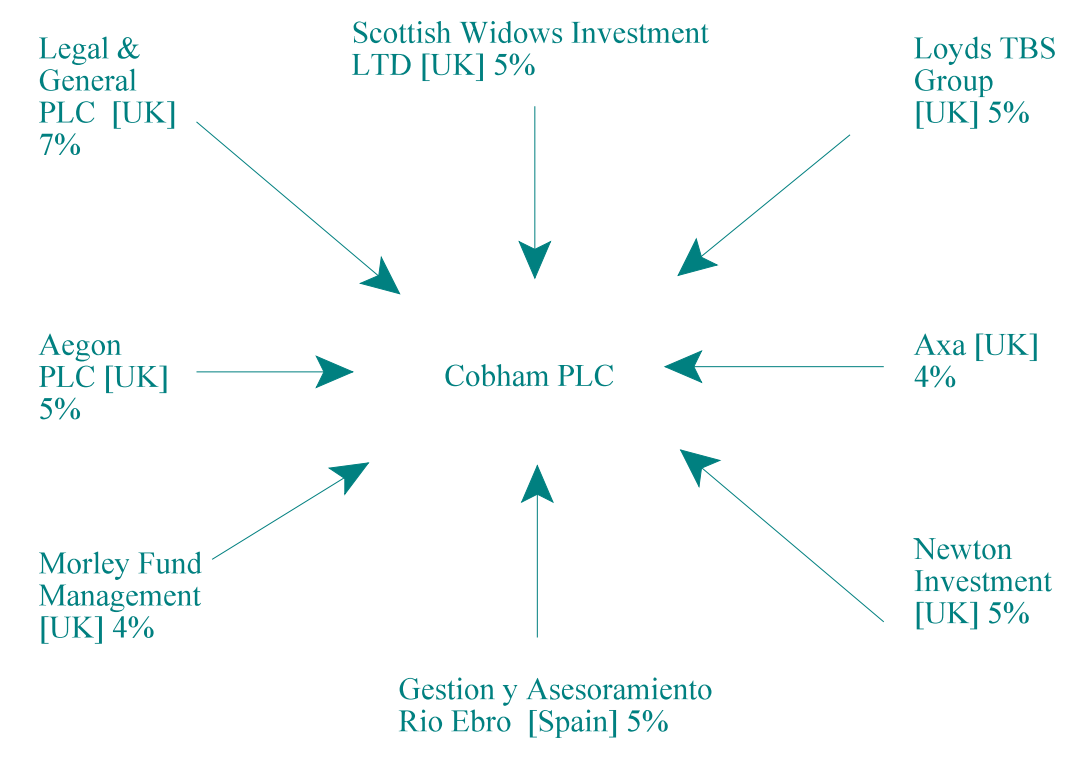

Figure 6.

shareholdings are, in fact, modest. The four most powerful shareholders all are American (Franklin Resources, Inc.; FMR Corporation; Ameriprise Financial, Inc.; and Capital Group) and have a combined ownership of shares held by the key shareholder group of some 45 percent, up from some 25 percent in $2004 .{ }^{15}$ The two largest U.K. shareholders in this group (Lehman Bros and Barclays Plc) jointly controlled 8 percent of shares in mid-2006.

A striking feature of Figure 5 is the 28 percent share of Rolls-Royce Plc owned by the U.S. company Franklin Resources, Inc. in mid-2006, up from some 17 percent in $2004 .{ }^{16}$ Since Franklin Resources is primarily an asset management company, it could be argued that its shareholdings are held purely for the financial benefit of the funds or clients whose assets it manages and not for its own business purposes, implying therefore that such a strong shareholding has no special strategic significance. But a stake as large as 28 percent might have much greater potential significance to an industrial group with defense interests wishing to influence Rolls-Royce corporate strategy in the future and, at least theoretically, Franklin could sell its shareholding at any time.

Finally, Figure 6 illustrates the shareholding profile for a smaller, second-tier U.K. defense supplier, Cobham Plc. Here, the ownership picture is much more traditional, which may be somewhat surprising given the recent transformation of the company into a global enterprise, itself owning numerous companies in other countries (as discussed earlier). All but one of the major shareholders are U.K. financial sector companies (Scottish Widows; Legal and General; Axa; Lloyds TSB; etc.), companies which would be expected to hold their investments for financial return rather than for the purposes of wielding strategic influence over corporate policy.

A more general examination of U.K. defense company ownership indicated that many of the U.S. and U.K. major investors noted in Figures 3 to 5 also were found to have extensive interests in many other defense contractors. This may imply nothing more than that, in mid-2006, the defense sector was particularly attractive to this range of capital providers and their prominence in the shareholder list is attributable only to financial stimuli in the form of potential shareholder return. Alternatively, it may have a wider meaning that is not immediately apparent and further research into the prominence and significance of certain key investors is clearly needed.

\section{Ownership implications and corporate governance}

What are the implications of the ownership profiles observed in this sample of the U.K.'s defense industry? The official government line on this was made abundantly clear in September 2005 in a speech by Lord Drayson, government minister for defense procurement who commented that the "U.K. defence industry is now defined in terms of where technology is created, where high value skills and intellectual property reside, and where the investment is made, not where the shareholders live." Furthermore, before its recent demise, the Department of Trade and Industry took the view that some foreign defense suppliers could be regarded as part of the U.K.'s defense industrial base. The French company Thales, for example, falls into such a category, now owning several small U.K. companies, operating in the U.K. through them, and receiving significant amounts of U.K. Ministry of Defence expenditure.

Against this official view, however, it could be argued that decisions on the future location of Drayson's key definitional attributes - technology creation, high-value skills, intellectual property, and actual investment (as well as production and employment) - in the defense sector may ultimately have a great deal to do with "where the shareholders reside." As noted, the American grip on U.K. defense company ownership is, without question, strengthening, drawing U.K.-based companies such as BAE Systems and Smiths Aerospace ever closer to the U.S. market and, in the case of Smiths, into a total U.S. takeover. In this latter case, it will be interesting in the future to observe how many of the Drayson list of key definitional attributes continue to apply to Smiths' U.K. operations, if any, under full American ownership.

Another important ownership issue which has come to prominence in recent years is that of corporate governance. The governance of companies in many different sectors of business has come under the spotlight in the last 20 years with scandals ranging from the weakness of the Japanese banking system, experience with 
pharmaceutical companies' behavior in the EU and in the U.S., the massive fraud associated with the collapse of Enron in the U.S. and Parmalat in Italy, and defense contract concerns in the U.K., U.S., and France.

But the purpose of the current drive toward enhanced corporate governance regimes across the world has more to do with its potential for improving competitiveness than with simply stamping out corrupt business practices. First, corporate governance is about who controls what in the business context and how well they are performing. The ownership issue is critical here. Evidence suggests that well-run companies with sound best practice corporate governance regimes are more attractive to investors since they are perceived to be operating in a way which maximizes the opportunity to secure sustainable competitive advantage in the market.

Second, where investor-owners are private equity concerns (as, for example, in the case of the significant shareholding in QinetiQ held by the Carlyle Group), these owners may be expected to actually influence the governance process itself. Private equity funds are distinct from other kinds of funds, such as mutual funds or hedge funds, mainly due to the fact that they own a significant proportion of a company's shares and take a longer time horizon on investments into account. Such capital providers are likely to become more involved in influencing decisions in their investee companies, particularly with regard to instituting or enhancing a specific corporate governance regime.

If good corporate governance helps determine corporate performance and efficiency, then ownership changes in the defense industry take on greater significance. There are few contributions to the literature to draw on regarding the linkage for defense companies between governance and performance. One study observed that under the market-based corporate governance system (also known as the Anglo-Saxon system) used in the U.S. and the U.K., defense firms consolidated faster and more effectively after the end of the Cold W ar in the U.S. and U.K. than did defense companies in Europe, and that they gained a comparative advantage in terms of profit margins, market share, and productivity not shared by European companies with their more inclusive stakeholder approach to the governance issue. ${ }^{17}$

Another scholar conducted a case study of the state-controlled Portugese defense industry to assess (a) the relative efficiency of the industry and whether the availability of government subsidies had increased technical efficiency and (b) whether the corporate governance environment surrounding the defense industry helped to enforce the desired improvement in efficiency. ${ }^{18}$ The study concluded that (a) the Portugese Ministry of Defense incentive regulations have not achieved their aims and (b) the corporate governance regime for the Portugese defense industry was in urgent need of complete overhaul, yet was not even on the government's agenda.

\section{Conclusions}

On the basis of the evidence drawn from a limited sample of U.K. defense supply companies employed in this study, one can draw some initial conclusions. Major U.K. defense companies have a strong American presence in their ownership profile and, increasingly, own U.S.-based companies themselves. The majority of the investor-owners are passive fund managers rather then industrial groups investing for reasons of corporate strategy influence. This, however, may be changing as target contractors (for example, Smiths Aerospace) are "cherry picked" in their entirety. In some circumstances, where a large private equity company holds a significant shareholding in a U.K. defense contractor (as with the Carlyle group and QinetiQ) there may be important concerns about how passive the investor will be. Overall, current ownership profiles do not appear to present a serious problem. However, large, passive owners with significant shareholdings in one or more key U.K. defense company can always choose to sell their stake in the company at short notice, possibly to another large foreign-based concern

In addition, there are a range of other important issues to consider. At a time when national security is a top government priority, identifying who or what actually owns and may seek to influence the key companies in the U.K. defense sector is essential. Yet, as noted, it is difficult to trace accurately at a point in time, and especially over a period of time, the real extent and nature of invisible ownership in the defense industry.

Furthermore, share ownership is transitory by nature and fully transferable, unless government retain a golden share to resist unwanted outcomes. In other industries, change in ownership can sometimes result in factory closure, lost investments, skill diminution, and corporate relocation to another country. Why should the defense industry, which is being driven increasingly into the global market, be any different? It is through these potential global transfers of investment, core competencies, skills, and, ultimately, production and employment that defense company ownership may really begin to matter as one of the last remaining bastions of British manufacturing is disassembled.

Another important issue may be a tendency toward potential suboptimal outcomes where companies with different ownership profiles and, therefore, corporate governance systems are drawn together in joint ventures, strategic alliances, technology partnerships, and such like. What happens when these governance regimes collide? Who wins and with what consequences?

Finally, from these initial observations, the degree of foreign ownership of major U.K. defense companies seems surprisingly high. Perhaps this reflects a further stage in the financial and industrial integration of business generally in the global economy and of U.S.-U.K. links in the defense sector in particular. U.S. and U.K. links in defense are extremely strong now and mirror closely their military cooperation in Iraq, Afghanistan, and in the so-called war on terror. Against this background, no economist would be surprised that U.S. investors have a healthy interest in U.K defense industry stocks, nor that both countries are showing ever-increasing interest in the acquisition of the other key players in the defense business. The same 
economist, however, would wonder what implications this ownership reshuffle will have for the future existence and survival of a viable, competitive European defense industrial base to challenge U.S. dominance in global markets.

Notes

Derek Braddon is Reader in Economics at the University of the West of England, Bristol, and Director of the university's Defence Economics Research Unit. This article is based on the Annual Public Lecture, given by Dr. Braddon, which launched the 11 th Annual Conference on Economics and Security in Bristol, 5 July 2007. He can be contacted at derek.braddon@uwe.ac.uk.

1. Braddon and Bradley (2005).

2. Kirkpatrick (2004).

3. Dunne, et al. (2007); Braddon (2000).

4. Matthews (2001).

5. Braddon (2004); Hartley (2003).

6. Hayward (2005).

7. Guay and Callum (2002); Hartley and Sandler (2003).

8. Dowdall (2004).

9. A term coined by the Rand Corportion in 2000; http://rand.org/pubs/documented _briefings/DB358/DB358.part1.pdf

10. Clearly, ownership changes occur regularly within the industry, so a date must be chosen if we are to examine the ownership pattern at any point in time. Mid-2005 was selected as such a date during the early phase of research for this article as it marked the apparent end of a major phase of defense industry consolidation.

11. The data for Figures 1 to 3 all are derived from Defence Systems Daily, May 2005, http://defence-data.com/ripley/pagerip 1.htm.

12. FAME (Financial Analysis Made Easy) is an Internet-based database of detailed company and financial information on nearly two million major public and private U.K. and Irish companies with summarized information for a further one million companies. It contains up to 10 years of data on each company. FAME allows one to search by any combination of over 300 criteria, including: geographic location, SIC code or activity description, number of employees, statement items, ratios, credit score/rating, legal form, year of incorporation, holding company/subsidiary, and merger and acquisition deals. Further information may be obtained from, and the database accessed through: http://www.uwe.ac.uk/library/resources/general/ databases/titles/fame.htm.

13. The data for Figures 4 to 6 all are derived from the FAME database.

14. Braddon and Bradley (2004).

15. Braddon and Bradley (2004).

16. Braddon and Bradley (2004).

17. Harper (1998)

18. Barros (2005)

References

Barros, C. 2005. "Governance and Incentive Regulation in Defense Industry Enterprises: A Case Study." European Journal of Law and Economics, Vol. 20, No. 1, pp. 87-97.

Braddon, D. 2000. Exploding The Myth? Lodnon: Routledge.

Braddon, D. 2004. "The Matrix Reloaded - What Future for the Defense Firm?" Defense and Peace Economics, Vol. 15, No. 6, pp.499-507.

Braddon, D. and J. Bradley. 2005. "What Lies Beneath? Who Owns UK Defense Companies and Does It Matter?" Frontiers in Finance and Economics, Vol. 2, No 1, pp. 68-81.

Dowdall, P. 2004. "Chains, Networks and Shifting Paradigms: the U.K. Defense Industry Supply System." Defense and Peace Economics, Vol. 15, No. 6, pp. 535550 .

Dunne, J.P., Garcia-Alonso, M, Levine. P, and R. Smith. 2007. "Determining the Defense Industrial Base." Defense and Peace Economics, Vol. 18, No. 3, pp. 199-221.

Guay, T. and R. Callum. 2002. "The Transformation and Future Prospects of Europe's Defense Industry.” International Affairs, Vol. 78, No. 4, pp. 757-776.

Harper, J.K. 1998. "Corporate Governance and Performance During Consolidation of the U.S. and European Defense Industries." Journal of Management and Governance, Vol. 2, No. 4, pp. 335-355. 
Hartley, K. 2003. "The Future of European Defense Policy: An Economic Perspective." Defense and Peace Economics, Vol. 14, No. 2, pp. 107-115.

Hartley, K. and T. Sandler. 2003. "The Future of the Defense Firm.” Kyklos, Vol. 56, No. 3, pp. 361-380

Hayward, K. 2005. "I Have seen the Future and it Works! The U.S. Defense Industry Transformation - Lessons for the U.K. Defense Industrial Base." Defense and Peace Economics, Vol. 16, No. 2, pp. 127-141.

Kirkpatrick, D. 2006. "Choose your Weapon: Combined Operational Effectiveness and Investment Appraisal and its Role in U.K. Defense Procurement." London: Royal United Services Institute.

Matthews, R. and J. Tredinnick. 2001. "Managing the Revolution in Military Affairs." Basingstoke, UK: Palgrave. 